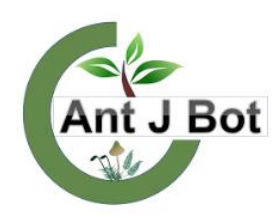

Received : 02.11.2017 Accepted : 18.12.2017

\section{Flammulina fennae Bas, A new record from Karz Mountain (Bitlis)}

\author{
Cemil SADULLAHOĞLU ${ }^{1 *}$, Kenan DEMIREL ${ }^{2}$ \\ ${ }^{1}$ Yuzuncu Yll University, Faculty of Science, Department of Biology, Van, Turkey \\ ${ }^{2}$ Ordu University, Faculty of Education, Department of Mathematics and Science Education, Ordu, Turkey
}

*csadullahoglu@yandex.com

\section{Flammulina fennae Bas, Karz Dağı'Indan (Bitlis) bir yeni kayıt}

Abstract: Flammulina fennae Bas (Physalacriaceae) is recorded for the first time from Turkey. Ecology, distribution, locality, and photographs related to macro and micromorphologies and a short description of the new record were given.

Key words: Flammulina fennae, Physalacriaceae, new record, Karz Mountain, Turkey.

Özet: Flammulina fennae Bas (Physalacriaceae) Türkiye’de ilk kez kaydedilmiştir. Yeni kaydın ekolojisi, yayılışı, lokalitesi, makro ve mikro fotoğrafları ve kısa bir deskripsiyonu verilmiştir.

Anahtar Kelimeler: Flammulina fennae, Physalacriaceae, yeni kayıt, Karz Dağı, Türkiye.

\section{Introduction}

Flammulina P.Karst. is a genus in the family Physalacriaceae Corner which has a cosmopolitan distribution, especially in temperate regions. Robert et al (2005; http://www. mycobank.org) and Index fungorum.org (accessed 1 November 2017) list 17 conformed species of Flammulina, most of which are edible (Ge et al., 2008).

Two Flammulina species, $F$. ononidis Arnolds and $F$. velutipes (Curtis) Singer, have been recorded from Turkey up to date. Although $F$. velutipes has been reported from many places of Turkey (Abatay, 1983; Demirel, 1998; Sesli, 1999; Solak et al., 1999; Öztürk et al., 2001; Uzun et al., 2004; Kaya et al., 2009), F. ononidis has been collected only from Samsun (Pekşen and Karaca, 2003).

During routine field studies in Karz Mountain (BitlisTurkey) some basidiomes were collected. Flammulina fennae Bas, was described as a new record according to the current checklists on Turkish macromycota (Sesli and Denchev, 2014; Solak et al., 2015) and the latest contributions to the basidiomycetous macrofungi of Turkey (Demirel and Koçak, 2016; Akata and Uzun, 2017; Aktaş et al., 2017; Demirel et al., 2017; Iş1k and Türkekul, 2017; Sesli and Vizzini, 2017; Uzun and Kaya, 2017; Uzun et al., 2017a,b).

The present study aims to make a contribution to the macrofungi of Turkey.

\section{Materials and Method}

Fungal specimens were collected from Obuz village, Karz Mountain (Tatvan-Bitlis-Turkey) in 2010. Morphological and ecological chracteristics of the samples were recorded during the field study and they were photographed in their natural habitats. Then, they were taken to the laboratory and microscopic investigations were carried out on them.

Microscopic investigation of the samples were done by using a Nikon light microscope. Reagents such as $5 \%$ $\mathrm{KOH}$ and Congo red were used. Identification was performed with the aid of the relevant literature (Bas, 1983; Ripkovà et all., 2010; Schafer and Kibby, 2015).

\section{Results}

Fungi Bartling

Basidiomycota R.T. Moore

Agaricales Underw.

Physalacriaceae Corner

Flammulina P. Karst.

Flammulina fennae Bas, Persoonia 12(1): 52 (1983)

Macroscopic features: Pileus $20-45 \mathrm{~mm}$ in diameter, convex-parabolic, smooth, slightly viscid, pale ochre yellow, when moist short translucently striate at margin of mature basidiocarps, thick-fleshed, rather elastic. Lamellae adnexed to adnate, sinuate, moderately distant, with numerous intermediate gills, white to pale cream. Stipe $25-90 \times 2-8 \mathrm{~mm}$, cylindric-tapered, mostly solid, tough, densely subtomentose, concolorous with the pileus at apex, becoming darker reddish brown to dark brown below. In large basidiocarps there are a few remarkable longitudinal grooves (Fig. 1a).

Microscopic features: Spores 5.8-7 × 4-4.5 $\mu \mathrm{m}$, ellipsoid to elongate-ellipsoid, thin-walled, smooth, hyaline, with small apiculus. Basidia 28-33 $\times$ 4.5-6. $\mu \mathrm{m}, 4$-spored, clamped. Cheilocystidia 35-70 × 6-15 $\mu \mathrm{m}$, scarce, utriform to lageniform, slightly thick-walled relatively to spore and basidium walls, hyaline. Pleurocystidia similar to cheilocystidia (Fig. 1b,c,d).

Specimen examined: Bitlis-Tatvan, Karz Mountain, Obuz village, mixed woodland, on buried roots, $38^{\circ}$ $26^{\prime} 625^{\prime \prime} \mathrm{K}, 42^{\circ} 22^{\prime} 467^{\prime \prime} \mathrm{D}, 1788 \mathrm{~m}, 02.10 .2010 . \mathrm{S} .036$.

\section{Discussions}

Flammulina fennae was added to Turkish mycobiota as the third member of the genus Flammulina. Macro and micromorphological properties of the newly recorded taxon agree with those described by Bas (1983) and Schafer and Kibby (2015). 


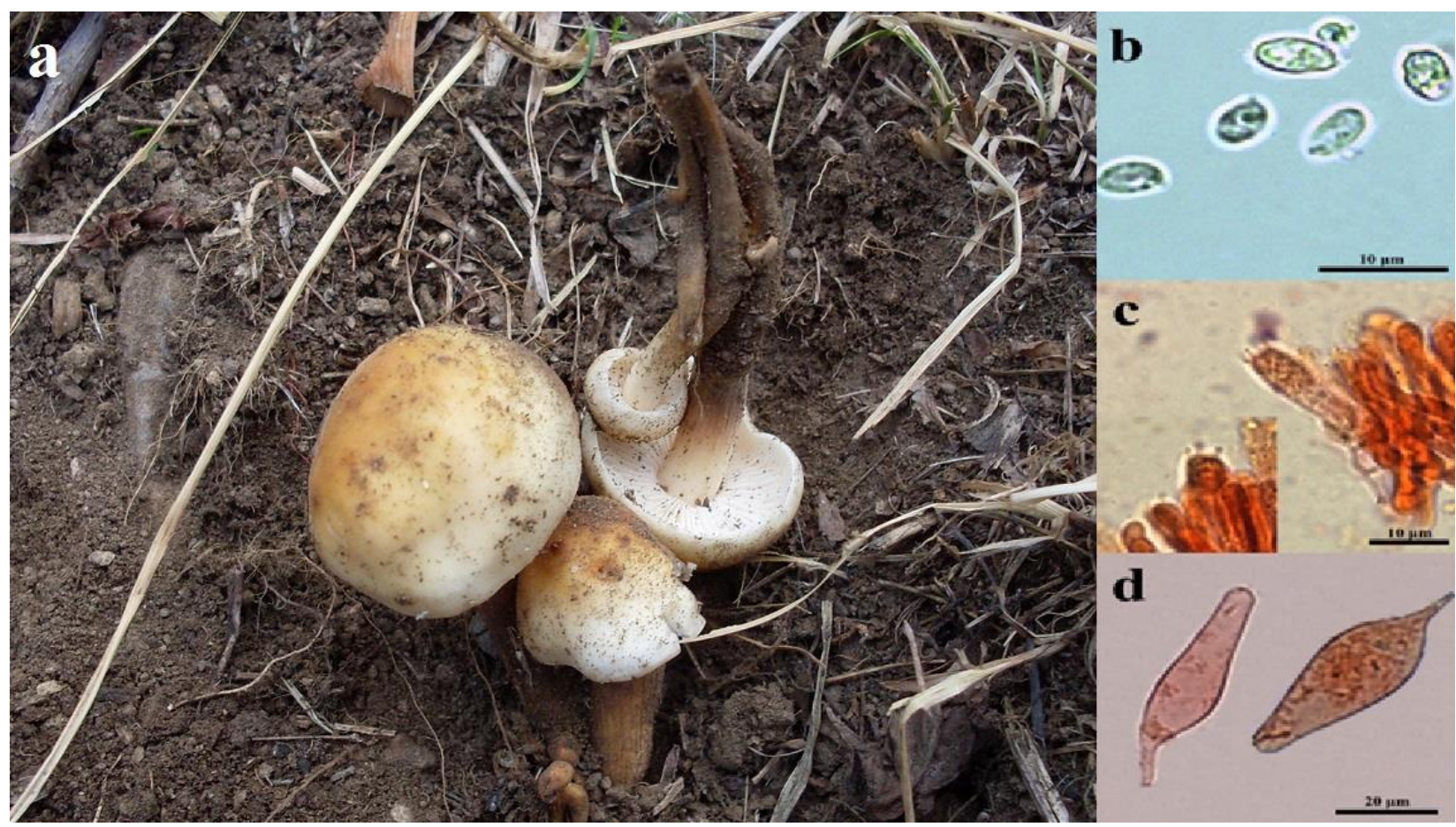

Figure 1. Flammulina fennae: a- basidiomata; b- basidiospores; c- basidia and basidioles, d- cheilocystidia.

Among the Flammulina species, $F$. velutipes and $F$. ononidis are morphologically similar to $F$. fennae. But both of them have larger spores. Though $F$. fennae has a spore size of $6-8 \times 4-4.5(-5) \mu \mathrm{m}$, spore sizes of $F$. velutipes and $F$. ononidis were reported as 7-11 $\times(2.5-) 3$ $4 \mu \mathrm{m}$, and as 8.5-12.5 $\times$ 4.5-5.5 $\mu \mathrm{m}$, respectively (Ripkova et al., 2010).

Field characteristics may also be used to distinguish these three species. Flammulina ononidis is known to associate with the roots of Ononis spinosa. Flammulina velutipes grows usually in winter season. But F. fennae has no association with Ononis and normally fruits outside winter season (Schafer and Kibby, 2015).

\section{Acknowledgments}

The authors are thankful to Yüzüncü Y1l University Research Fund (BAP Project No. 2011-FBE-YL-009) for the financial support.

\section{References}

Abatay M (1983). Studies on the fungus species infecting woody plants in the East Black Sea Region. Ormancilik Araştırma Enstitüsü Yayınları 118: 57-67.

Akata I, Uzun Y (2017). Macrofungi Determined in Uzungöl Nature Park (Trabzon). Trakya University Journal of Natural Sciences 18(1): 15-24.

Aktaş S, Öztürk C, Pamukçu D (2017). Nallıhan (Ankara) İlçesi Makrofungusları. The Journal of Fungus 8(1): 60-67.

Bas C (1983). Flammulina in western Europe. Persoonia 12: 51-66.

Demirel K (1998). Contributions to the macrofungi flora of West Black Sea Region. Yüzüncü Y1l Üniversitesi Fen Bilimleri Enstitüsü Dergisi 5(1): 23-27.

Demirel K, Koçak MZ (2016). Zilan Vadisinin (Erciş-VAN) Makrofungal Çeşitliliği. The Journal of Fungus 7(2): 122-134.

Demirel K, Uzun Y, Keleş K, Akçay ME, Acar İ (2017). Macrofungi of Karagöl-Sahara National Park (ŞavşatArtvin/Turkey). Biological Diversity and Conservation 10(2): 32-40.

Ge ZW, Yang ZL, Zhang P, Matheny PB, Hibbett DS (2008). Flammulina species from China inferred by morphological and molecular data. Fungal Diversity 32: 59-68.

Index Fungorum (2017). http://www.indexfungorum.org/Names/Names.asp. Accessed 25 October 2017.

Işık H, Türkekul İ (2017). A new record for Turkish mycota from Akdağmadeni (Yozgat) province: Russula decolorans (Fr.) Fr. Anatolian Journal of Botany 1(1): 1-3.

Kaya A, Uzun Y, Karacan İH (2009). Macrofungi of Göksun (Kahramanmaraş) District. Turkish Journal of Botany 33: 131-139.

Kirk PM, Cannon PF, Minter DW, Stalpers JA (2008). Dictionary of the Fungi. 10th ed. Wallingford, UK: CAB International.

Öztürk C, Doğan HH, Kaşık G (2001). Additions to the macrofungus flora of Ermenek (Karaman). Selçuk Üniversitesi Fen Edebiyat Fakültesi Fen Dergisi 18: 61-66. 
Pekşen A, Karaca G (2003). Macrofungi of Samsun Province. Turkish Journal of Botany 27: 173-184.

Ripková, S., Hughes, K., Adamčik, S., Kučera, V. \& Adamčikova, K. (2010). The delimitation of Flammulina fennae. Mycological Progress 9: 469-484.

Robert V, Stegehuis G, Stalpers J (2005 Onward (Continuously Updated). The MycoBank Engine and Related Databases. Available online at http://www.mycobank.org.

Schafer D, Kibby G (2015). Flammulina fennae new to Britain. Field Mycology 16(3): 97-99.

Sesli E (1999). The macrofungi determined in A5 (Samsun-Bafra) and A6 (Ordu)]. The Herb Journal of Systematic Botany 6(1): 95-98.

Sesli E, Denchev CM (2014). Checklists of the myxomycetes, larger ascomycetes, and larger basidiomycetes in Turkey. 6th edn. Mycotaxon Checklists Online. (http://www.mycotaxon.com/resources/checklists/sesli-v106-checklist.pdf): $1-136$.

Sesli E, Vizzini A (2017). Two new Rhodocybe species (sect. Rufobrunnea, Entolomataceae) from the East Black Sea coast of Turkey. Turkish Journal of Botany 41: 200-210.

Solak MH, Işıloğlu M, Gücin F, Gökler I (1999). Macrofungi of İzmir Province. Turkish Journal of Botany 23: 383 -390.

Solak MH, Işıloğlu M, Kalmış E, Allı H (2015). Macrofungi of Turkey, Checklist, Vol. II. İzmir, Turkey: Üniversiteliler Ofset.

Uzun Y, Acar İ, Akçay ME, Kaya A (2017a). Contributions to the macrofungi of Bingöl, Turkey. Turkish Journal of Botany 41(5): 516-534.

Uzun Y, Kaya A (2017). A Hypogeous Lactarius sp., New to Turkish Mycobiota. The Journal of Fungus 8(2): 163-167.

Uzun Y, Kaya A, Karacan İH, Yakar S (2017b). New additions to Turkish Agaricales. Biological Diversity and Conservation 10(2): 8-13.

Uzun Y, Keleş A, Demirel K, Solak MH (2004). Some macrofungi from Bayburt Province in Turkey. Bulletin of Pure and Applied Sciences 23(1): 47-55.

Cite this article: Sadullahoğlu C, Demirel K (2018). Flammulina fennae Bas, A New Record from Karz Mountain (Bitlis). Anatolian Journal of Botany 2(1):19-21. 